REVISTA ANDALUZA DE ANTROPOLOGÍA

NÚMERO 15: ACTIVIDADES TURÍSTICAS, CIUDAD Y PATRIMONIO CULTURAL: MIRADAS CRÍTICAS. TOURIST ACTIVITIES, CITY AND CULTURAL HERITAGE: CRITICAL GLANCES SEPTIEMBRE DE 2018

ISSN 2174-6796

[pp. 74-102]

http://dx.doi.org/10.12795/RAA.2018.15.04

\title{
EL CURT ESTIU DE LA TURISMEFÒBIA. MOVIMENTS SOCIALS I CONFLICTE URBÀ AL BARRI DEL POBLENOU, BARCELONA
}

\section{THE SHORT SUMMER OF TOURISMPHOBIA. SOCIAL MOVEMENTS AND URBAN CONFLICT IN THE NEIGHBORHOOD OF POBLENOU, BARCELONA}

José A. Mansilla López

Escuela Universitaria de Turismo Ostelea - Universitat de Lleida (UdL)

Observatori d'Antropologia del Conflicte Urbà (OACU)

\section{Resumen.}

L'any 2017 podria ser considerat, a Barcelona, com l'any de la turismefòbia. Els canvis socials i econòmics viscuts per la ciutat durant les darreres dècades s`han vist acompanyats per l'aparició de tot un entramat de moviments socials íntimament lligats a aquestes transformacions, així com als seus impactes. Al barri del Poblenou, el diagnòstic realitzat per \#EnsPlantem, Veïns en Perill d'Extinció, apunta a la turistificació com un dels seus principals reptes. Mitjançant una aproximació etnogràfica de dos anys al voltant d’aquesta plataforma, el present article pretén mostrar el paper exercit per aquest tipus de moviments davant de l'aplicació de polítiques urbanes contemporànies de tall neoliberal vinculades al turisme.

Palabras clave.

Barcelona, barris, turistificació, gentrificació, moviments socials 


\begin{abstract}
.
The year 2017 could be considered, in Barcelona, as the year of tourismphobia. The social and economic changes experienced by the city during the last decades have been accompanied by a complex network of social movements closely linked to these transformations, as well as their impacts. In the neighborhood of Poblenou, the diagnosis made by \#EnsPlantem, Neighbors in Danger of Extinction, points to the touristification as one of its main challenges. Through an ethnographic approach of two years around this platform, this article aims to show the role played by this type of movements around the application of neoliberal contemporary urban policies linked to tourism.
\end{abstract}

\title{
Keywords.
}

Barcelona, neighbors, touristification, gentrification, social movements.

\section{INTRODUCCIÓ}

Welcome to the charming Poblenou. This old industrial site has been transformed into an area of design art studios, shops and apartments. It is only 15 minutes away from the city center, a fantastic location [...]. As a seaside area, Poblenou is a great place to come for finding seafood [...]. The Rambla Poblenou is the central hub of the area. Here you are be able to find young and old enjoying a coffee or sitting in a bench watching the World goes by. The Rambla is also the main shopping street in the area [...]". Vídeo "The Catalan Manchester", de la empresa Let Oh-Barcelona.com y su guía "to Europe’s most exciting city".

El 17 d'agost de 2017, un atemptat terrorista va provocar setze morts i desenes de ferits en les cèntriques Rambles de Barcelona ${ }^{2}$. Fins a aquest moment, la temporada turística de la capital de Catalunya, però també d'altres pobles i ciutats de la resta de l'Estat, podria haver estat denominada, parafrasejant la coneguda novel-la de Hans Magnus Enzensberger ${ }^{3}$, com "el curt estiu de la turismefòbia". No obstant això, el salvatge atropellament i el posterior abatiment a trets dels presumptes terroristes van absorbir la totalitat del debat públic, de manera que els acalorats enfrontaments dialèctics -i no tan dialèctics- al voltant del turisme que s'anaven manifestant des de feia mesos als principals mitjans de

1. Per a més informació:https://www.youtube.com/watch? $\mathrm{v}=0 \mathrm{xO} \quad 6 \mathrm{nO} 87 \mathrm{ak} \& \mathrm{t}=24 \mathrm{~s}$

2. Aquest article parteix d'una recerca actualitzada que va donar lloc al text "Vecinos en peligro de extinción. Turismo urbano, movimientos sociales y exclusión socio-espacial en Barcelona”, publicat a la Revista PASOS, n², vol., 16, 2018, pp. 279-296.

3. La novel.la a la qual es fa referència és "El corto verano de la anarquía", publicat el 2006 per l’editorial Anagrama.. 
comunicació, així com a l'arena política, d’àmbit no només català, sinó també espanyol i europeu, van perdre sobtadament protagonisme ${ }^{4}$.

Tot i que la premsa havia estat recollint articles i columnes d'opinió sobre el paper del turisme a la ciutat comtal des de molts mesos abans, i moviments socials com l'Assemblea de Barris per un Turisme Sostenible (ABTS) havien dut a terme, entre d'altres, importants accions de denúncia sobre el paper de plataformes com Airbnb ${ }^{5}$ en el teixit social de la ciutat, el debat es veuria fortament accelerat a finals de juliol. Llavors, un petit grup d'encaputxats va assaltar un dels autobusos que recorren habitualment la ciutat, els coneguts com Bus Turístic, al costat de l'estadi del Barcelona FC, punxant-li les rodes i fent-hi una pintada, on es podia llegir "El turisme mata els barris", en un dels seus laterals. Uns dies després, el dia 30, el col-lectiu juvenil de l'esquerra independentista catalana ARRAN reivindicava l'assalt mitjançant un vídeo penjat en una coneguda plataforma en línia ${ }^{6}$, on senyalaven que l'acció havia estat realitzada a manera d"'autodefensa contra el barricidi". Segons l'empresa que gestiona el servei, Transports Metropolitans de Barcelona (TMB), els danys causats ascendien a un total de 1.849,24 euros, inclosa la retirada del vehicle (EFE, 2017).

Al barri del Poblenou, aquest tipus d'accions directes havien tingut també certa rellevància. Part dels participants en una manifestació convocada el 5 de maig per la plataforma veïnal \#EnsPlantem, la qual havia aglutinat més de tres-centes persones en protesta contra "l'alt preu dels lloguers per la pressió turística al barri i la gentrificació" (Savall, 2017), van llançar ous i globus amb pintura contra les façanes de dos hotels de la zona. Lacció va comptar amb certs moments de tensió, ja que a més de la pintura i els ous, algun dels manifestants va llançar un pot de fum a les portes d'un dels establiments. Lincident va provocar la immediata resposta per part de l'Ajuntament de la ciutat, el qual va condemnar "els incidents a Poblenou. El que cal és aplicar amb fermesa el PEUAT, combatre els lloguers abusius i l'especulació als barris"7.

Els fets fins aquí relatats evidencien la conflictivitat que el turisme, sota certes circumstàncies, pot arribar a provocar. Així, considerat tradicionalment com una indústria sense xemeneies, el turisme podria haver subestimat "els impactes ambientals, socials, culturals, econòmics, religiosos, etc., [que genera com] activitat [...], entenent-

4. Huete i Manteco (2018) recullen en el seu article de la Revista PASSOS quaranta referències a la turismefòbia només en l’àmbit estatal, tot i que també assenyalen referències a la mateixa en diaris europeus com The Independent i el Daily Mail.

5. Per a més informació: https://directa.cat/actualitat/un-grup-dactivistes-destapa-una-xarxa-de-pisos-turistics-illegals-barcelona-administrats

6. Per a més informació: https://www.youtube.com/watch?v=NqIzGkbUloI

7. Per a més informació: https://twitter.com/G Pisarello/status/860875813918576641 
se com impactes els xocs o conseqüències de l'activitat turística a les diferents àrees esmentades" (Gruter, 2013). Pel que fa al discurs turismefòbic, els sociòlegs Raquel Huete i Alejandro Mantecón (2018) distingeixen dues línies principals a l'hora de presentar el fenomen: d'una banda, una línia deslegitimadora basada en "una política orientada a l'assoliment de beneficis econòmics immediats a partir de l'augment de l'arribada de turistes, en detriment de la planificació d'un desenvolupament sostenible i de la gestió i adaptació de la demanda a les característiques específiques de cada destinació" (Ibíd.: 16), i, d’altra banda, una línia "critica [amb] els efectes del turisme massiu a les ciutats [que] s'incorpora a un ideari contestatari més ampli en el qual s'articulen expressions antiglobalització capitalista íntimament associades amb moviments sociopolítics que plantegen diferents reivindicacions» (Ibíd.: 16) ${ }^{8}$. Així, com assenyala l’antropòleg Claudio Milano "en els últims anys, els moviments socials i el turisme han començat a tenir una relació molt propera" (2017: 6), de manera que serien considerats com a factors negatius a interposar-se en la necessària estabilitat social i política que requereix la continuació del procés d’acumulació capitalista (Cordero, 2006).

En definitiva, mentre una orientació es mostraria pragmàtica i possibilista, encaixant perfectament en el marc de les polítiques de tall neoliberal implementades a les ciutats europees durant les últimes dècades (Harvey, 2001 i 2013), la segona estaria vinculada a la consideració de la ciutat com a mercaderia (Lefebvre, 1969; Delgado, 2017; Mansilla, 2018), mostrant unes relacions socials conflictuals inserides, i aparentment ocultes, darrere de les dinàmiques turístic-urbanitzadores, les quals compten, a més, amb el protagonisme d'uns moviments socials que intenten denunciar la situació i proposar alternatives com a agents col-lectius.

\section{METODOLOGIA I HIPÒTESI}

Pel que fa al present treball em centraré en l'última de les aproximacions destacant un element principal: l'íntima relació entre els moviments socials i la consideració de les ciutats com a elements ineludibles de l'esfera productiva capitalista (Kling and Posner, 1990). D’aquesta manera, a través de l'anàlisi a un fenomen emergent, la plataforma \#EnsPlantem al Poblenou, Barcelona, disseccionaré el paper que juguen els moviments socials en el marc de les polítiques neoliberals urbanes. Per fer això em centraré, principalment, en les diferents respostes que \#EnsPlantem ha donat a la dinàmica que, segons el seu propi diagnòstic, viu el barri: la turistificació, entenent per tal aquell procés pel qual es transforma un bé històric, cultural o natural -però també un barri com entramat social i espacial-, en un producte valuós per al mercat turístic (Zúñiga, 2014).

8. El psicòleg social Horaci Espinosa assenyala l'existència d'intents de despolititzar, i deslegitimar, el malestar subjectiu que genera el turisme en determinats emplaçaments. Per a més informació: https:// www.eldiario.es/catalunya/opinions/Turismefòbia-Patologizar-malestar-social 6 660443975.html 
La metodologia utilitzada en aquest article és principalment qualitativa (Berg, 2007), com no podia ser d'una altra manera tractant-se d'una aproximació etnogràfica. No obstant això, aquesta es veurà complementada amb una altra de tipus quantitatiu (Bernard, 2006) amb l'objectiu de realitzar una triangulació metodològica (Posthill, 2015) en un intent d’apuntalar al màxim la proposició inicialment presentada. D’aquesta manera, el primer pas a l'hora de dur a terme el procés etnogràfic (Velasco i Díaz de Rada, 1997) va ser la realització d'una revisió en profunditat de bibliografia rellevant relacionada amb el tipus de dinàmica estudiada, no només llibres o articles vinculats, sinó també notícies, declaracions, pàgines webs i la participació en xarxes socials dels principals actors involucrats. Aquesta apareixerà referenciada conforme vagi sent útil a l’argumentació plantejada.

El treball de camp per a la present investigació es va dur a terme entre els mesos de maig de 2016 i de 2018 i les tècniques utilitzades van ser, principalment, lobservació participant -en assemblees, accions reivindicatives, ocupacions, manifestacions, fòrums i grups de WhatsApp, Twitter, etc.-, la realització d'entrevistes i el manteniment de converses i diàlegs informals amb els principals actors participants. D’aquesta manera, en total s'ha assistit a 13 assemblees i comissions diverses, cinc manifestacions, dues de les quals van acabar amb l'ocupació d'equipaments i solars públics, i dues festes de barri. A més, s'han dut a terme 17 entrevistes $^{9}$ a diferents participants, s'han mantingut quatre diàlegs $i$, finalment, s'han transcrit dos debats mantinguts a través de les xarxes socials. Totes elles han estat protagonitzades, principalment, per membres de l'Assemblea Social del Poblenou (ASP9), l'Ateneu la Flor de Maig, Fem Rambla i la Plataforma \#EnsPlantem, així com per integrants d’alguns dels horts urbans del barri, socis i Junta Directiva de l'Associació de veïns i veïnes del Poblenou (AVVP9), treballadors d’antigues fàbriques del barri, voluntaris de l'Arxiu Històric del Poblenou i veïns i veïnes sense vinculació a moviment o entitat alguna.

La metodologia etnogràfica va ser considerada com adequada per a aquest tipus d'investigació ja que permet una aproximació a lobjecte d'estudi des de dins, i admet descriure i interpretar els processos socials posant especial atenció en els seus participants. Per a la realització del treball de camp no es van establir diferències basades en el gènere ni en l'edat. Amb l'objectiu d'evitar repeticions, s'han seleccionat els extractes més representatius de les entrevistes i els esdeveniments observats.

\section{EMPRESARIALISME URBÀ, TURISME I MOVIMENTS SOCIALS}

No és fins a principis de la dècada del 2000 que els estudis urbans comencen a desmuntar la consideració que els usos turístics i residencials romanien separats a les ciutats (Judd,

9. Al final del article s'inclou un llistat de les persones entrevistes que apareixen en el present article. 
2003). Així, com assenyalen Russo i Richards (2016), els turistes busquen ara un contacte més proper amb els locals; cosa que s'ha convertit en una nova experiència a oferir per part de les destinacions.

D'altra banda, des dels anys 70, les ciutats s'han convertit en peces fonamentals per als processos d'acumulació i circulació del capital (Harvey, 2007; Brenner, Peck i Theodore, 2015). Així ho mostren els exemples de ciutats americanes tan dispars com Valparaíso (Caimanque, 2015) i Río de Janeiro (Guterman et al, 2015) o, ja dins de l'Estat espanyol, Sevilla (Díaz, 2009 i 2016), Tenerife (García Herrera, Smith, i Mejías, 2007), Granada (Medela i Salguero, 2016) o la mateixa Barcelona (Delgado 2005 i 2007). Tanmateix, com bé recordaren Judd and Parkinson (1990), les polítiques destinades a aquesta finalitat solen generar ciutats segmentades que afavoreixen l'afluència de classes mitjanes en detriment de les baixes. De vegades aquesta determinació es troba, fins i tot, en el seu $A D N$ urbanístic. Aquest seria el cas, un cop més, de la capital de Catalunya on, tal com recull la geògrafa Rosa Tello, el seu Pla General Metropolità de 1976 apostava per "el manteniment a la comarca de persones de renda mitjana i elevada" (1993: 513 ).

D’altra banda, aquesta cerca per mantenir i atreure classes mitjanes i capitals reforçaria el procés de fragmentació i exclusió. Les propostes elaborades per autors com Richard Florida (2009a i 2009b) d'acord amb les anomenades classes i ciutats creatives abunden en aquesta direcció. L’objectiu d’aquestes polítiques descansaria sobre la idea que la creació d'atmosferes urbanes dedicades a la producció cultural i el consum, acabarien funcionant com a autèntics motors de re-desenvolupament (Lloyd, 2002). Ara bé, aquesta aparició de grups socials amb majors ingressos i noves demandes desencadenaria l'aparició de processos, com el de gentrificació, molts més amplis i menys miops que les inicials consideracions sobre el tema de fa unes dècades -les quals restringien dinàmiques similars al mercat immobiliari- i haurien acabat desembocant en tota una re-configuració del paisatge de les ciutats en clau de classe (Smith, [1996] 2012; Slater, 2011).

Aquests nous veïns i veïnes de classe mitjana reclamarien experiències urbanes similars als turistes, de manera que els efectes de les dues presències, així com els processos que generen, arriben a ser indistingibles en el marc dels canvis urbans (Fuller i Michel, 2014). Alguns autors (Hiernaux i González, 2014) arriben a denominar a aquestes dinàmiques "gentrificació criolla" referint-se al cas de les ciutats llatinoamericanes. La diferència amb el model més clàssic consistiria en el fet que, d'una banda, el turista apareix com un "productor de lespai"10 (Lefebvre, 2013), tant simbòlic com material i, de l'altra, no es produeix una substitució permanent d'una classe social per una altra, sinó que les classes mitjanes-baixes són desplaçades per habitants no residents, és a dir, per turistes.

10. L'espai que produirien -i trobarien, en un procés dialèctic-, els turistes coincidiria amb aquell demandat per les classes mitjanes, és a dir, "un mirall de la seva realitat, representacions sedants, la imatge d'un món social en què tenen el seu lloc, precís, etiquetatge i assegurat “(Lefebvre, 2013: 345). 
No obstant això, aquesta violència simbòlica (Bourdieu, 1997) que genera el turisme no és, avui dia, patrimoni exclusiu de les ciutats de l'hemisferi oriental, sinó que els canvis en el paisatge urbà, les modificacions en el comerç tradicional, etc., apareixen com un comú denominador per a urbs de tot el globus (Romero, 2001).

Aquesta manifestació de relacions de poder asimètriques, disputes per l'espai i control social a la ciutat (Harvey, 2013; Aricó i Fernández, 2013) es presenta en aquestes situacions mitjançant una competència pels recursos i els serveis que ofereix (Fuller i Michel, op. cit.), però també a través d'un impacte directe sobre els preus de l'habitatge, la introducció de noves formes de consum i, en general, les transformacions en l'entorn urbà.

En els darrers temps, diferents autors, provinents sobretot d'Europa i els Estats Units, proposen abordar les investigacions al voltant de les tensions generades per les polítiques urbanes neoliberals -en tota la seva amplitud-, i les seves resistències enfocant tres elements fonamentals: l'àmplia gamma i l'heterogeneïtat dels actors involucrats, la varietat de respostes que els moviments socials poden oferir i, finalment, les propostes per reconstruir la ciutat des de baix (Mayer, 2016). D’aquesta manera, manifesten la seva insatisfacció "with the rationalist and empiricist social movement research paradigm" (Thorn, Mayer i Thron, 2016: 22) de les anàlisis basades, per exemple, en l'Estructura d'Oportunitats Polítiques (EOP), reclamant el retorn als treballs de Castells ${ }^{11}$ en un intent de destronar el seu llarg regnat.

En aquesta mateixa línia podríem incloure a David Harvey quan subratlla que les pràctiques de despossessió relacionades amb, per exemple, el mercat de l'habitatge o la privatització de lespai urbà, es podrien considerar formes secundàries d'explotació, ja que actualment constituirien part de la clau de volta de l'acumulació del capital (2013). Així, el neoliberalisme, com a procés de reorganització de la producció capitalista, crea nous actors històrics, diferents constel-lacions d'interessos, les amenaces a aquests interessos $\mathrm{i}$ les principals condicions per a les transferències del poder (Tilly, 1977) i la seva disputa. És mitjançant aquesta perspectiva que podrien analitzar-se moviments i accions com la Plataforma \#EnsPlantem, Veïns en Perill d'Extinció, de Barcelona, a la qual dedicaré els següents paràgrafs.

11. Manuel Castells, a La Qüestió Urbana (1976), atorgava als moviments socials urbans una potencial funció transformadora i els equiparava als sindicats clàssics de l'esfera productiva. En obres posteriors, La ciutat i les masses: sociologia dels moviments socials urbans (1986), va temperar aquesta aproximació al fenomen. Molt més genèriques són les consideracions establertes per autors com Mario Diani (1992, 2010), Donatelladella Porta (2009), i de forma conjunta Diani i Della Porta ([1999] 2006). Aquests posen el focus, a l'hora de definir els moviments socials, en la seva especificitat en la coordinació d’accions collectives i en la constitució de xarxes d'actors d'un perfil ampli i heterogeni. 


\section{EL LLARG HIVERN DEL DESCONTENTAMENT AL POBLENOU}

Parafrasejant a William Shakespeare, el barri del Poblenou porta patint un hivern del descontentament des de fa més de cinquanta anys. De tota manera, aquest descontentament està menys vinculat als versos del poeta anglès al voltant dels fets de Ricardo III, i més a les polítiques neoliberals viscudes pel conjunt dels britànics a l'avantsala de l'arribada de Margaret Thatcher al poder el $1979^{12}$.

Des dels intents de transformació de part del seu front marítim en una Copacabana barcelonesa (Arroyo, 1999) a través del conegut com a Pla de la Ribera de 1965 (Tatjer, 1973; Navas, 2016), fins a les transformacions operades al barri com a conseqüència de la construcció de la Vila Olímpica dels Jocs del 1992 (Makhlouf, 2014; Aricó, Mansilla i Stanchieri, 2016) i la temptativa de convertir aquest antic Manchester català en un SoHo Barcelonés mitjançant el Pla 22 @ (Marrero, 2003), els antics terrenys ocupats per una de les més altes concentracions de teixit fabril del continent han estat testimonis del canvi d'orientació d'una ciutat tradicionalment industrial a una altra bolcada en el consum i els serveis (Capel, 2005 i 2016), amb especial incidència en aquelles activitats vinculades amb les noves tecnologies de la informació i la comunicació (TIC) (Mansilla, 2014).

El paradigma de la nova economia, però, no ha tingut finalment presència considerable ni al Poblenou, ni a la ciutat de Barcelona ${ }^{13}$. Com demostren les dades disponibles de l'any 2015, només el 30\% de les empreses instal-lades al 22@ es trobaven sota el paraigua de les noves tecnologies, sent el 52,7\% empreses ja existents que es traslladaven al nou Districte, mentre que gairebé el 70\% el copaven hotels i companyies vinculades a les assegurances, els serveis financers i el màrqueting (Ajuntament de Barcelona, 2016). Així, el procés de desindustrialització -de tipus clàssic- que va prendre nova empenta amb plans com el 22@es va veure acompanyat, no només per una dinàmica d'especulació urbanística i financera, sinó també per un increment significatiu d'hotels (Figura 1.-) i altres allotjaments turístics que han buscat compensar el fracàs relatiu de larribada d’empreses de la nova economia (Clarós, 2013; Charnock, Purcell i Ribera-Fumaz, 2014).

12. S'atribueix a l'últim primer ministre laborista dels 70 s, la frase "now, is theWinter of our discontent". TheGuardian. Per a més informació:https://www.theguardian.com/news/2011/jan/10/weatherwatch-jim-callaghan-winter-discontent

13. A mitjans de 2018, salta la notícia que Facebook ssinstal-larà a l'antiga Torre Abgar, actual Torre Glòries, al 22 @. No obstant això, finalment la que s'instal.la és una subcontracta de la companyia, el Competence Call Center (CCC), encarregada de controlar les fakenews per a Europa. Per a més informació veure: https://elpais.com/economia/2018/05/07/actualidad/1525714881_102628.html 
Figura 1. Hotels, categoria i localització exacta al Districte 22@.

\begin{tabular}{|c|c|c|}
\hline $\begin{array}{l}\text { Hotel Hilton Diagonal Mar } \\
\text { Barcelona }\end{array}$ & $\begin{array}{l}\text { Passeig del Taulat, 262-264 } \\
\text { (Barcelona) }\end{array}$ & Hotel $5 *$ \\
\hline Hotel Amrey Diagonal & $\begin{array}{l}\text { Avinguda Diagonal, } 161 \\
\text { (Barcelona) }\end{array}$ & Hotel 3 * \\
\hline Hotel GBB 4 Barcelona & $\begin{array}{l}\text { Carrer del Doctor Trueta, } 164 \\
\text { (Barcelona) }\end{array}$ & Hotel 4 * \\
\hline Hotel Barcelona Princess & $\begin{array}{l}\text { Avinguda Diagonal, } 1 \\
\text { (Barcelona) }\end{array}$ & Hotel $4^{*}$ \\
\hline Hotel Confortel Barcelona & $\begin{array}{l}\text { Carrer de Ramon Turró, 196- } \\
198 \text { (Barcelona) }\end{array}$ & Hotel $4 *$ \\
\hline Hotel Barceló Atenea Mar & $\begin{array}{l}\text { Passeig de Garcia Fària, 37-47 } \\
\text { (Barcelona) }\end{array}$ & Hotel $4 *$ \\
\hline Hotel Sallés Pere IV & $\begin{array}{l}\text { Carrer de Pallars, 128-130 } \\
\text { (Barcelona) }\end{array}$ & Hotel $4 *$ \\
\hline Hotel Apsis Porta Marina & $\begin{array}{l}\text { Carrer de Sancho de Ávila, 32- } \\
34 \text { (Barcelona) }\end{array}$ & Hotel $4 *$ \\
\hline Hotel Me Barcelona & $\begin{array}{l}\text { Avinguda Diagonal, 272-286 } \\
\text { (Barcelona) }\end{array}$ & Hotel 5 * \\
\hline $\begin{array}{l}\text { Hotel \& Spa Villa Olimpic@ } \\
\text { Suites }\end{array}$ & $\begin{array}{l}\text { Carrer de Pallars, } 121 \\
\text { (Barcelona) }\end{array}$ & Hotel $4 *$ \\
\hline $\begin{array}{l}\text { Hotel Rafaelhoteles } \\
\text { Diagonal Port }\end{array}$ & $\begin{array}{l}\text { Carrer de Lope de Vega, } 4 \\
\text { (Barcelona) }\end{array}$ & Hotel $4 *$ \\
\hline Hotel AC Barcelona & $\begin{array}{l}\text { Passeig del Taulat, } 278 \\
\text { (Barcelona) }\end{array}$ & Hotel $4 *$ \\
\hline Hotel Husa Barcelona Mar & $\begin{array}{l}\text { Carrer de Provençals, } 10 \\
\text { (Barcelona) }\end{array}$ & Hotel $4 *$ \\
\hline $\begin{array}{l}\text { Holiday Inn Express } \\
\text { Barcelona City 22@ }\end{array}$ & Pallars, 203, (Barcelona) & Hotel 3 * \\
\hline $\begin{array}{l}\text { Hotel ibis Barcelona Pza } \\
\text { Glories } 22\end{array}$ & $\begin{array}{l}\text { Calle Ciutat de Granada 99, } \\
\text { (Barcelona) }\end{array}$ & Hotel 2 * \\
\hline
\end{tabular}

Font: Ajuntament de Barcelona, 2016

Aquesta deriva cap als serveis i el turisme que ha viscut el 22@, suposadament aliena a les intencions inicials de l’administració municipal impulsora d’aquest pla, està en línia amb la conversió de Barcelona en una ciutat turística comparable a altres destinacions àmpliament consolidades -com París, Roma o Londres-, situant-la com la tercera ciutat d'Europa i desena, a escala mundial, pel que fa a nombre de visitants i despesa, i com la cinquena ciutat europea i la vintena del món més visitada (Ajuntament de Barcelona, 2015), a més de com la tercera destinació europea en la celebració de congressos i altres esdeveniments (Castán, 2018). Això ha fet, tal com indica el Pla Estratègic de Turisme de Barcelona 2020, que el turisme sigui "part inherent i constitutiva del fenomen urbà actual" 
(Ajuntament de Barcelona, 2016b), de manera que, com a activitat socioeconòmica, dóna forma a la ciutat al mateix temps, i de forma dialèctica, que la ciutat determina les possibilitats del turisme (Ibíd.). A més, ha portat a la mateixa institució municipal a plantejar el procés Repensem el 22@, el qual persegueix “endegar un procés de participació ciutadana per repensar conjuntament una estratègia davant dels actuals reptes socials, econòmics i urbanístics del Poblenou i el 22@"14.

\section{1. \#EnsPlantem, Veïns en Perill d'Extinció}

El 20 de maig de 2016, una petita multitud es va donar cita a un dels emplaçaments més emblemàtics del Poblenou; una petita rotonda conformada per l'encreuament del carrer Doctor Trueta i la Rambla del barri, just davant del Casino de l'Aliança, vetust teatre de Barcelona que actualment comparteix edifici amb un concorregut restaurant. Larbrat i antic Passeig del Triomf, veritable eix de la vida social del Poblenou i el seu principal punt de trobada, és, actualment, l'única Rambla de tot Barcelona que desemboca a la platja, fet que li ha atorgat un atractiu considerable. La convocatòria havia estat realitzada per tres dones que comptaven amb una nodrida experiència dins dels moviments socials del barri i es va difondre, des d'uns dies abans, a través de diferents vies (llistes de correu electrònic, cartelleria variada, missatges de WhatsApp, boca a boca, etc.), tant entre diferents col-lectius i persones del teixit social local com entre el veïnat general.

Asseguda a terra, la improvisada assemblea va atreure l'atenció dels passejants, molts dels quals s'aturaven sorpresos per una acció com aquella en lloc tan significatiu. Sense més, les tres dones van exposar el motiu principal de la trobada: conformar una plataforma veïnal per lluitar contra el procés de turistificació que, segons elles, vivia el barri, així com contra els seus efectes, entre els quals van esmentar l'increment dels preus de l'habitatge i els lloguers, el canvi en la fesomia de l'entorn -l'aparició d'establiments turístics i comerços que poc o res tenen a veure amb les necessitats més quotidianes dels veïns i veïnes- i la superpoblació de bars i terrasses als tradicionals espais de socialització del barri, destacant la Rambla, cosa que estava generant l'expulsió de tots aquells que no podien adaptar-se a la dinàmica de transformació que estava vivint al Poblenou. Naixia així \#EnsPlantem, Veïns en Perill d'Extinció.

Entre les primeres decisions que va prendre la plataforma \#EnsPlantem, hi va haver la realització d'una sèrie d'accions a l'espai urbà del barri amb l'objectiu de fer visible les reivindicacions plantejades. En aquest sentit es va convocar, pel 5 de juny de 2016, la que es va denominar una "Ruta de l'Especulació". Aquesta va consistir en una cercavila que va recórrer diversos emplaçaments del Poblenou considerats com especialment rellevants pels membres de l'assemblea. Entre aquests es van trobar espais que, en breu, havien

14. Per a més informació: https://www.decidim.barcelona/processes/Repensem22a 
d'acollir establiments hotelers, així com antics solars convertits en horts urbans, com el denominat Hort Indignat $1^{15}$, espai ocupat per l'extinta Assemblea Social del Poblenou (ASP9), hereva del moviment 15M al barri, i que pertanyia a l'anomenat SAREB (Societat de Gestió d’actius procedents de la Reestructuració Bancària) o Banc Dolent, és a dir, lorganisme constituit pel Govern de l'Estat per adquirir actius immobiliaris pertanyents a entitats financeres en procés de sanejament.

Figura 2.- La Ruta de l'Especulació al seu pas per un dels antics horts (05-06-2016).

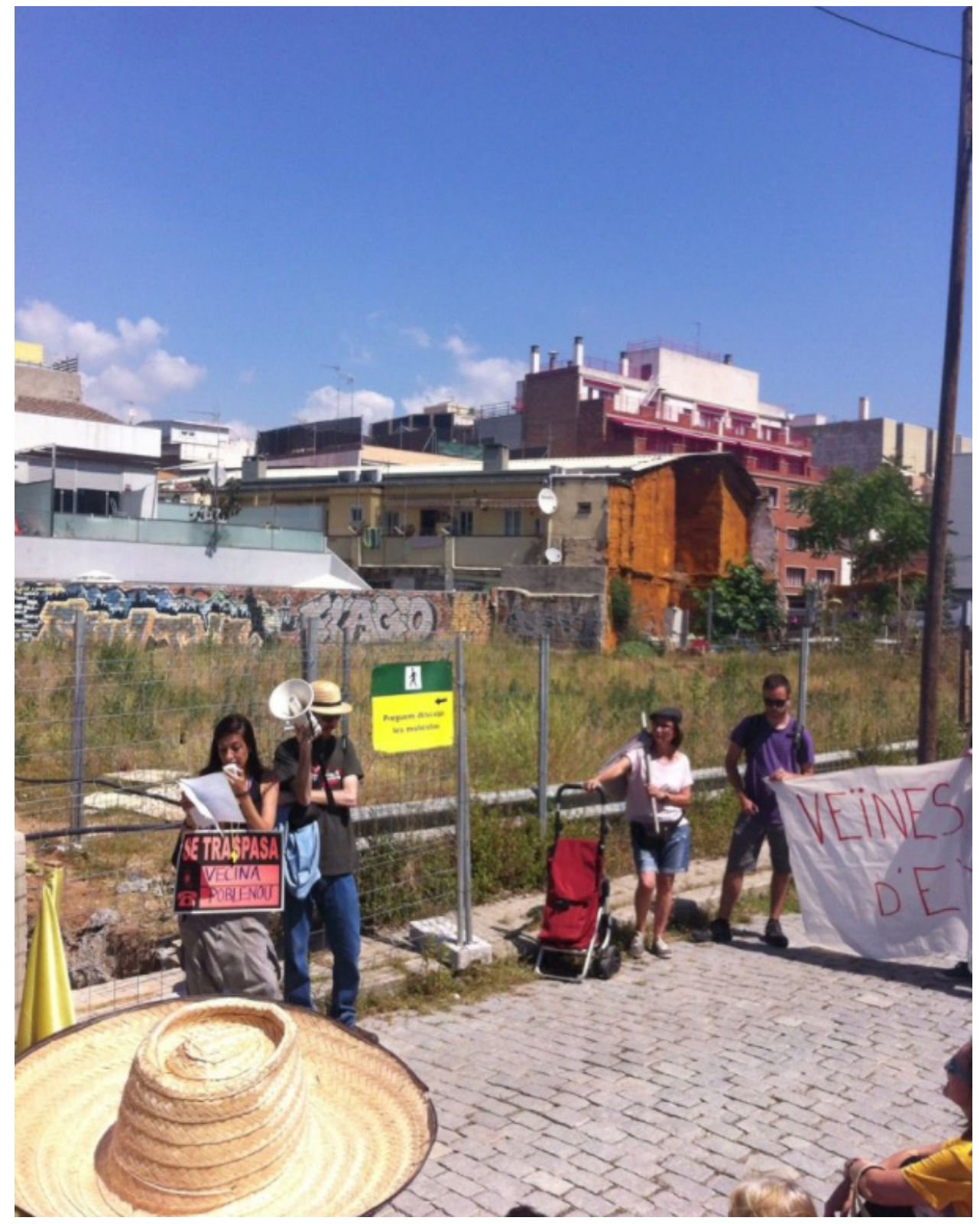

Font: @EnsPlantemP9

15. El maig de 2018, data en la qual aquest article està escrit, l'Hort fa temps que ha estat desallotjat pels seus nous propietaris, els quals persegueixen la construcció al solar d'un complex d'habitatges de gamma alta.. 
El destí final de l'itinerari era la "recuperació d’un espai verd per al barri" i la realització "d'una plantada popular de flors", fets que es van produir quan els participants a la Ruta van ocupar, de manera simbòlica ${ }^{16}$, un solar d'uns $10.000 \mathrm{~m}^{2}$ situat a la cruilla dels carrers Llacuna, Llull, Roc Boronat i Ramon Turró i on, a més d’estar pendent la ubicació d’una zona verda per part de l'Ajuntament de la ciutat, estava prevista la construcció de dos nous hotels. Segons els ocupants, aquests dos hotels suposarien un augment de 1.000 places hoteleres per a un barri on "els immobles s'han encarit, [s'] obren comerços que no satisfacin les necessitats dels veïns sinó dels turistes i [es dóna una] presència cada vegada més massiva de visitants estrangers en els bars i terrasses"(La Vanguardia, 2016). D'aquesta manera, la idea darrere d'aquest moviment social es vehicularia inicialment al voltant de a) una lluita contra l'increment del preu de l'habitatge, b) les transformacions del paisatge urbà i c) determinades concepcions al voltant de la forma de consumir lespai, allunyades de les més tradicionals per part dels veïns i veïnes. Com em va assenyalar la Rosa, una de les fundadores de la Plataforma, aquesta comença la seva marxa perquè "no sestava fent res, faltava un moviment al barri que lluités pel dret a l'habitatge [...] i l'espai públic. Calia plantar-se ${ }^{17}$ literalment i metafòrica”.

Les primeres reunions preparatòries d'\#EnsPlantem es van dur a terme, precisament, en alguns dels espais que havien estat denunciats i assenyalats en la "Ruta de l'Especulació" i per participants de moviments socials ja consolidats al Poblenou. Tornant a Rosa,

"La idea es va forjar en l'Hort 1 [...], cridem a gent de la Flor ${ }^{18}$, de l'Octubre ${ }^{19}$, gent propera que pensàvem que estarien interessats a participar i ens vam reunir durant dos mesos [...] Sempre havíem dit que calia començar a treballar al Poblenou, muntar alguna cosa ...."

Relacionat amb això, la Roser, una altra de les entrevistades, subratlla les possibilitats que ofereix l'espai urbà per al naixement de nous moviments, així com per al desenvolupament d'accions, quan assenyala que:

"El barri ha viscut cicles de mobilitzacions [...], portava un temps més parat, bé, fent coses però a nivell més intern, $\mathrm{i}$ ara aquest pic ha estat pel tema del turisme, però evidentment això no hauria estat possible sense mobilitzacions anteriors i per persones que han participat en aquestes mobilitzacions".

16. El maig de 2018, més de dos anys després de l’ocupació, l'Hort de La Vanguardia segueix funcionant..

17. \#EnsPlantem traduït al castellà és Nos Plantamos.

18. Ateneu la Flor de Maig. Antiga cooperativa que, després d’un període d’ocupació, en 2014 va ser comprada per l'Ajuntament de Barcelona i cedida a l'Associació Flor de Maig per a usos culturals i socials. Per a més informació:https://laflordemaig.cat/

19.Casal Independentista del Poblenou. Per a més informació: https://www.facebook.com/octubrepo$\underline{\text { blenou/ }}$ 
Una cosa que estaria en la línia del que Walter Nicholls (2008: 848) assenyalés en relació a les xarxes d'insurrecció urbana, és a dir, aquelles relacions especials i espacials que sestableixen entre diferents actors en aquest mitjà únic que és la ciutat.

\subsection{L'increment del preu de l'habitatge}

L'eix fonamental sobre el qual giren les reivindicacions d'\#EnsPlantem és l'increment del preu de l'habitatge, tant de lloguer com de compra, element aquest que accentuaria el caràcter material de la lluita de la plataforma com a moviment social a la ciutat (Thorn, 2012).

Les estadístiques de l'Institut Català del Sòl (INCASOL) respecte al preu de l'habitatge al Poblenou indiquen que, des de l'any 2013, primera dada disponible, fins al 2017, el $\mathrm{m}^{2}$ de les cases en compra/venda ${ }^{20}$ va passar dels 3.117,3€ als 4.347,4€, és a dir, gairebé un $40 \%$ d'increment per al període de cinc anys. Per a l'habitatge de lloguer ${ }^{21}$, l'increment és del $32,13 \%$, des dels $10,57 € / \mathrm{m}^{2}$ del 2014 , fins als $13,97 € / \mathrm{m}^{2}$ de 2017. Si imaginem una superfície mitjana dels habitatges d'entorn els $70 \mathrm{~m}^{2}$-el 62,6\% dels habitatges del barri tenen una superfície que oscillla entre els 60 i els $120 \mathrm{~m}^{222}$-, això hauria suposat passar dels 739,90 euros/mes als 977,61 euros/mes de renda de lloguer .

Els preus assolits fan impossible la vida al barri als veïns i veïnes de la zona. Així relatava la Roser la seva situació personal,

"Me n'he hagut d'anar del barri al Clot, que tampoc està tan lluny, que estic bé, però buscava per aquí, però no ho vaig trobar [...], l'únic que trobaves eren zulos de 40 metres quadrats i clar, si volies compartir pis amb algú, no pots ... i a part, molt cars ... així que te nanaves pel Besòs o cap amunt, tot i que el Clot $^{23}$ també està pujant bastant".

Per enfrontar aquesta situació, al febrer de 2018, conjuntament amb l'Associació de Veïns i Veïnes del Poblenou (AVVP9) i altres entitats del barri, \#EnsPlantem va posar en marxa la Comissió d'Habitatge del Poblenou. L'objectiu de la Comissió és, en paraules de Robert, un dels seus membres,

"Informar-se de casos d’expulsió de veïns i veïnes pels preus del lloguer i, després,

20. La dada del preu del $\mathrm{m}^{2}$ presentat considera tant l'habitatge nou com la de segona mà. La font que fa servir l'INCASOL és la del Col-legi de Registradors de la Propietat, Béns Mobles i Mercantils d'Espanya..

21. Lestadística del mercat del lloguer a Catalunya està basada en el registre de les fiances de lloguer dipositades a l'INCASOL.

22 Dades del Gabinet Tènic de Programació de l'Ajuntament de Barcelona. Per a més informació: http://www.bcn.cat/estadistica/castella/documents/barris/68 MA Poblenou 2016.pdf

23.Tant el barri del Clot com el Besòs formen part del Districte Sant Martí. 
aconseguir que el veïnat s'organitzi per poder negociar els casos de manera col-lectiva, que seria la manera de pressionar els propietaris i institucions per aturar els lloguers abusius “.

D’aquesta manera, la idea és oferir una resposta conjunta a un repte que, encara que es viu de forma individual, no deixa de tenir una incidència àmplia sobre el teixit social del barri. Entre les decisions preses per la Comissió, hi va haver obrir un punt d’informació permanent al Poblenou, al Casal del Barri situat a la Rambla, i organitzar-se a un nivell territorial més gran, de ciutat, amb altres col-lectius que mantenen objectius similars. Així, el març d'aquest mateix any, \#EnsPlantem i la Comissió van participar en l'esdeveniment Coordinem-nos! Trobada de Col-lectius en lluita per l'habitatge. En Coordinem-nos es van dur a terme diferents tallers informatius sobre qüestions com els desnonaments, l'acompanyament, l’okupació o la legislació vigent al voltant del lloguer.

Malgrat això, l'acció en què ha participat \#EnsPlantem i que més impacte, almenys a escala mediàtica ${ }^{24}$, ha tingut ha sigut Mudança de Protesta, el maig de 2018. La idea rere aquesta iniciativa era posar de manifest, a través de l'organització i acompanyament d'una mudança simbòlica, els denominats "desnonaments invisibles", és a dir, aquells que es produeixen no tant perquè els inquilins no puguin pagar la hipoteca o el lloguer -encara que de vegades el nivell de la pujada ho impossibilita-, sinó perquè els propietaris decideixen, unilateralment, no renovar els contractes i expulsar els llogaters, de manera que, després d'una reforma, poden tornar a posar l'immoble al mercat a preus marcadament superiors. Tal com assenyala la web de l'acció,

"Els barris de Barcelona s'estan buidant de veïns de forma silenciosa. Aquests desnonaments invisibles són conseqüència en gran part de la finalització de 44.000 contractes de lloguer que es preveu que hi haurà d'aquí a dos anys i l'abusiu augment dels preus (un 20\% de mitjana). Cal lluitar per visibilitzar aquesta greu situació i revertir-la”.

Desenes d’activistes i veïns i veïnes del barri van acompanyar el camió de la mudança pels carrers del Poblenou denunciant que no es tractava "d'una mudança voluntària” sinó que "els especuladors ens expulsen del barri" (López-Vallejo, 2018).

24. Entre d'altresTV3http://www.ccma.cat/324/els-veins-del-poblenou-es-muden-en-protesta-contra-la-pressio-immobiliaria/noticia/2853910/, El Periódicohttps://www.elperiodico.com/es/amp/ noticias/barcelona/solidaridad-vecinal-contra-los-desahucios-invisibles-6801513? twitter impression=true, El Paíshttps://elpais.com/ccaa/2018/05/05/catalunya/1525532706 381513.html?id externo_rsoc=whatsappiBetevéhttp://beteve.cat/mudanca-protesta-especulacio-immobiliaria-poblenou/ 
Figura 4.- La mudança de protesta al Poblenou (10-05-2018).

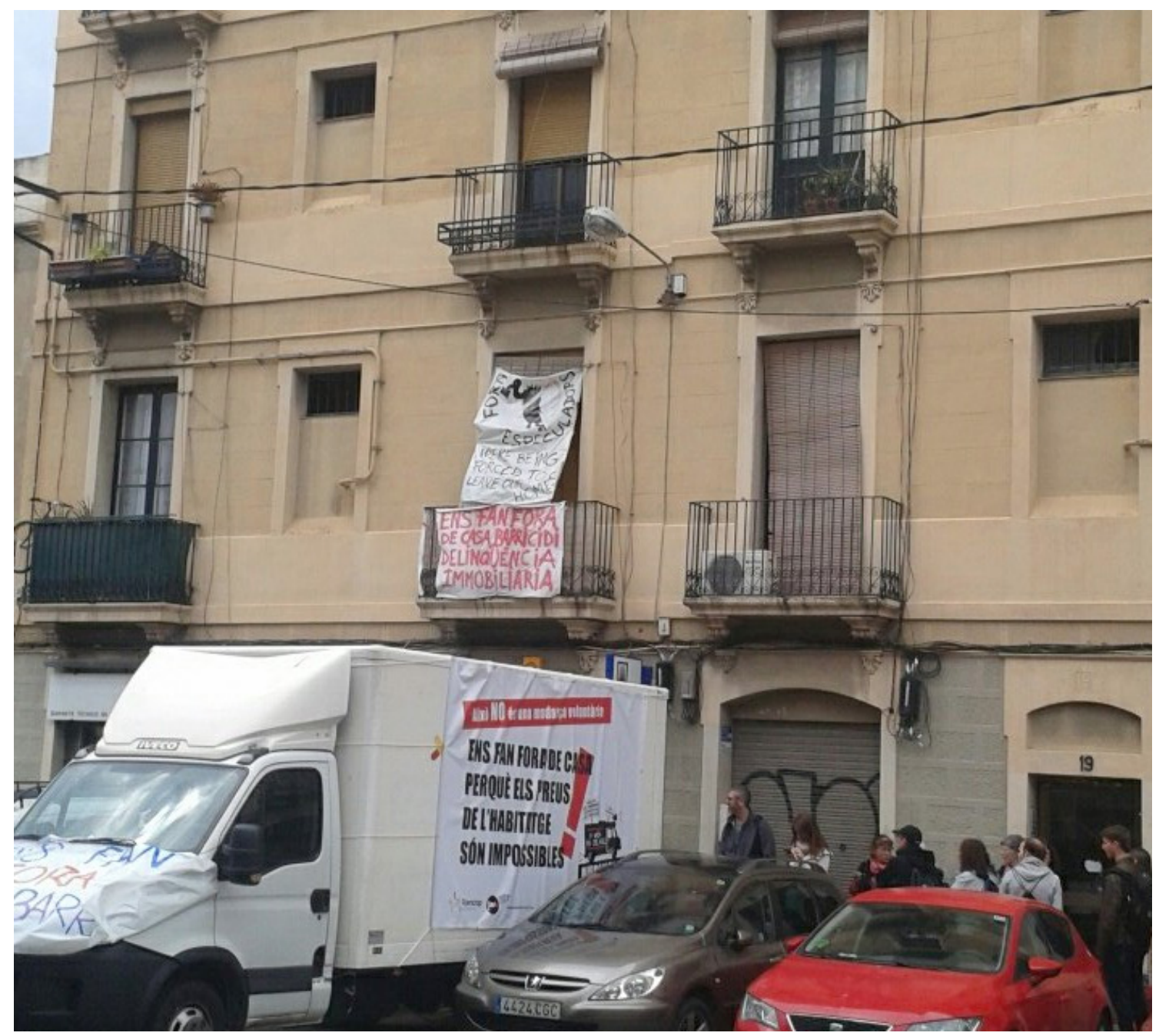

Font: Pròpia

\subsection{Els canvis al paisatge urbà}

Pel que fa als canvis produïts en la fesomia de l'entorn i l'estructura productiva del barri, les estadístiques de l'Ajuntament de Barcelona semblen donar la raó a aquells que pensen que, efectivament, està canviant, això és, que el Poblenou s’està terciaritzant. Així, segons l'informe realitzat pel Gabinet Tècnic de Programació municipal, entre els anys $2010 \mathrm{i}$ 2016, lactivitat vinculada al turisme i l'hostaleria va passar de representar el 5,6\% al 9,9\%, és a dir, un increment de gairebé el $77 \%$, mentre que el comerç tradicional i la indústria van passar, respectivament, des del $28,7 \%$ al $25,4 \%$, i del $50,3 \%$ del $37,7 \%$, durant el mateix període ${ }^{25}$.

25. Les mateixes estadístiques indiquen que el sector d’oficines va passar del 8,8\% al 16,4\%, el que podria reflectir la importància i influència de la posada en marxa del Districte 22 @. Per a més informació: http://www.bcn.cat/estadistica/castella/documents/barris/68_MA_Poblenou_2017.pdf 
Els efectes d'aquesta dinàmica han portat al fet que, cap a finals de 2017, al Districte de Sant Martí hagués censats 37 establiments turístics -entre hotels, apartaments i pensionsamb més d'11.500 places, quan només cinc anys abans, el 2010, únicament n’existien 29, el que suposava un total de 9.679 places. A això caldria sumar-hi unes 2.324 places en pisos complets ofertats a la plataforma Airbnb ${ }^{26}$, amb un increment de més del $25 \%$ en el període abans assenyalat (Ajuntament de Barcelona, 2016).

Les activitats d'\#EnsPlantem al voltant d'aquesta situació, no només es van basar en locupació simbòlica i material de solars propers a hotels en construcció, tal com he comentat anteriorment, sinó també en diferents accions destinades a denunciar la relació que la transformació del barri en destinació turística estava tenint sobre la vida quotidiana dels seus veïns i veïnes. Així, tornant a la manifestació del 5 de maig de 2017 que va ser titllada, des de diferents àmbits i mitjans de comunicació, com una demostració de turismefòbia per comptar, en el seu recorregut, amb el llançament de globus de pintura i pots de fum a la façana d'un hotel, Robert, de nou, ens comenta que,

"No va passar res de l'altre món. Uns tres-cents veïns i veïnes es manifestaven i van realitzar dues accions de caràcter simbòlic (alguns ous amb pintura i un pot de fum) per evidenciar alguns dels culpables de la gentrificació i substitució social que pateix el veïnat del Poblenou (empreses hoteleres, immobiliàries, fons d'inversió ...) “.

Tan diferents grups polítics, com a part del sector hostaler de la ciutat, es van llançar immediatament als mitjans a criticar l'acció i van exigir a l'Ajuntament de la ciutat que "posés fi a la turismefòbia" (Benvenuty, 2017) ${ }^{27}$.

Des d'\#EnsPlantem, però, tenen una visió diferent sobre el tema, així com el seu mateix anàlisi de la situació:

"Estàvem en un context on desenes de veïns i veïnes es veien forçades a abandonar les seves

26. Cal assenyalar, però, que alguns dels pisos que sofereixen a través d'Airbnb compten amb llicència HUT, és a dir, que també formarien part de l’oferta reglada d’allotjaments turístics al barri. Com Airbnb no té l'obligació de demanar els seus anunciants el codi HUT és impossible saber el nombre total que compta amb llicència i quins no. Tanmateix, una revisió detinguda de loferta del portal mostra que al voltant de 89 dels habitatges oferts podrien comptar amb llicència HUT legal. Això suposaria que caldria restar als 236 aquests 89 per conèixer l'oferta real no regulada del portal. D’altra banda, algunes vegades, pisos complets són oferts per habitacions, en comptes de per unitat. Això fa que, possiblement, loferta d'Airbnb al Poblenou sigui més gran de la que mostra la web de insideairbnb.com. Sigui com sigui, tots dos factors podrien equilibrar el nombre final, no afectant significativament l'aproximació de 236 habitatges complets totals.

27. Des del Gremi d'Hotelers de la ciutat es va assenyalar que "Ni tan sols l'alcalde accidental, Gerardo Pisarello, va condemnar els fets d'una manera contundent [...]. Allò no va ser ni acte simbòlic, ni performance, tal com va declarar un dels organitzadors per televisió. Va ser un acte de violència. I exigim a l'Ajuntament que posi fi a la criminalització i demonització del turisme, que deixin de posar en dubte les seves bondats i de destacar sempre els seus problemes. A més, està plovent sobre mullat". Per a més informació: http://www.lavanguardia.com/local/barcelona/20170509/422401678446/turismefòbia-hoteleros-ayuntamiento-ada-colau-vandalismo.html 
cases al carrer Llull ${ }^{28}$ per les obres de dos hotels -els hotels del solar de La Vanguardia-. Es volia posar de manifest la problemàtica de l'especulació immobiliària. Crec que el lobby turístic es va posar nerviós i van moure (sic) els seus contactes. Els partits polítics van sortir a condemnar una mobilització veïnal".

A més d’aquestes accions, la plataforma va mantenir una línia d'acostament amb diferents grups polítics i institucions municipals amb l'objectiu de, per una banda, donar a conèixer la situació que estava vivint el barri i, de l'altra, tractar d'influir en la regulació municipal vinculada al control i planejament de les instal-lacions i equipaments turístics que, al llarg de 2016 i 2017, es va estar discutint a l'Ajuntament.

Figura 5.- Reunió de representants d'\#EnsPlantem amb la Síndica de Greuges (05-082016).

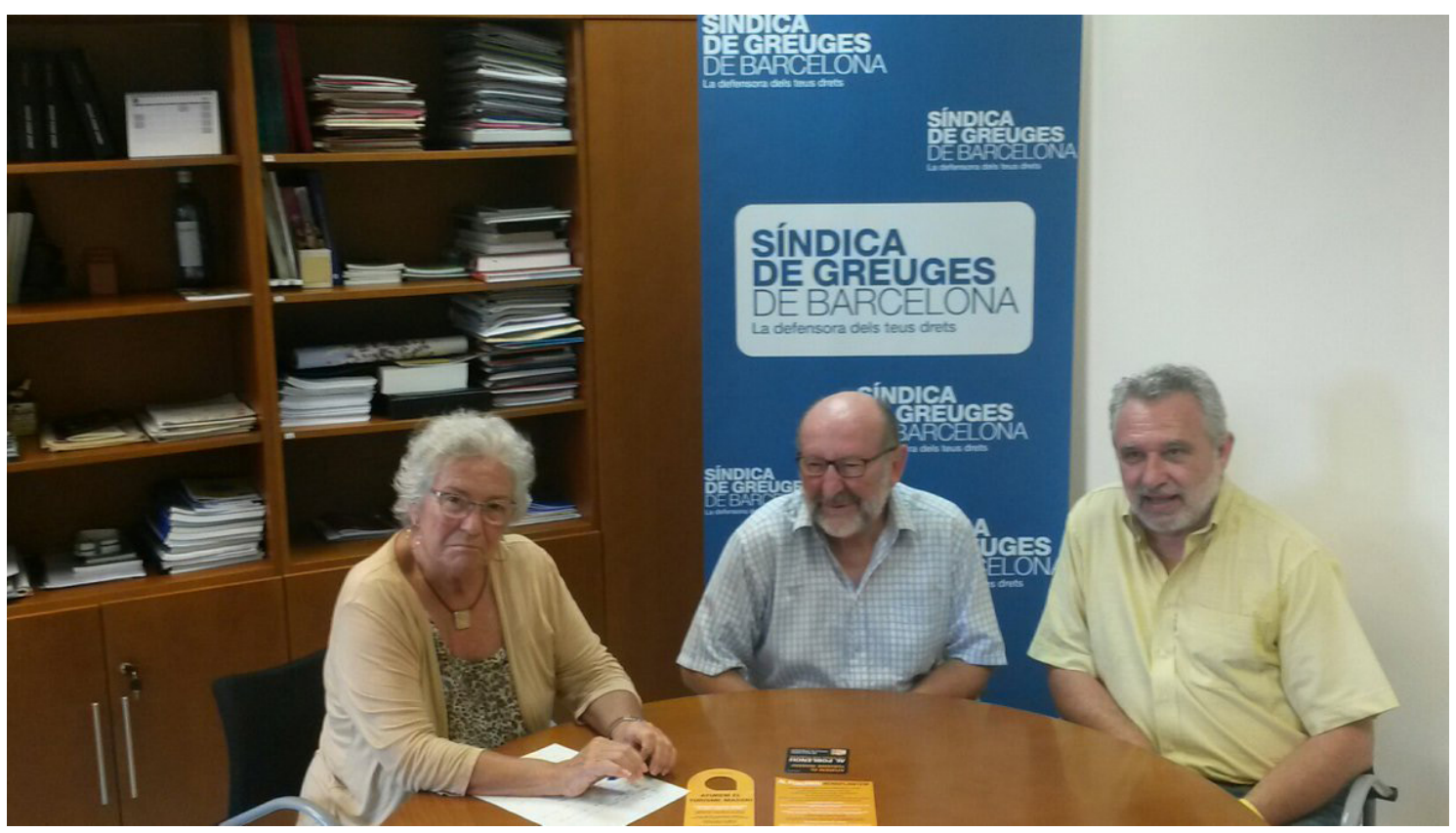

Font: @EnsPlantemP9

Els resultats d'aquesta i altres accions van ser satisfactoris, ja que el 27 de gener de 2017 el Ple Municipal aprovava el Pla Especial Urbanístic d'Allotjaments Turístics (PEUAT), el qual considerava al barri del Poblenou com Zona 1, és a dir, aquella on no es permet la implementació de cap nou tipus d’establiment turístic ni l'ampliació de places dels establiments existents ${ }^{29}$.

28. El març de 2017, tres blocs d'habitatges del carrer Ramon Llull van haver de ser desallotjats per perill d'ensorrament. Just davant s'estaven construint dos hotels, als quals es va responsabilitzar immediatament de la qüestió. Per a més informació: http://www.lavanguardia.com/local/barcelo$\underline{\text { na/20170315/42900776476/desalojados-tres-edificios-calle-llull-poblenou-grietas-hotel.html }}$

29. Per a més informació: http://ajuntament.barcelona.cat/pla-allotjaments-turistics/es/ 


\subsection{La privatització de carrers i places}

Les activitats d'\#EnsPlantem van continuar, al llarg de 2016, amb diferents accions relacionades amb els eixos de denúncia anteriorment ressenyats. Així, el dia 14 de juny es va organitzar una altra assemblea, seguida d'un sopar improvisat, i el 26 de juliol una cassolada a la mateixa Rambla del Poblenou. L'objectiu d’ambdues accions va ser, primer, fer una re-apropiació veïnal d'un espai altament significatiu del barri el qual, segons la plataforma, havia estat pres per bars i restaurants mitjançant la disposició de les seves terrasses i, segon, sumar més gent a la plataforma. La importància de la recuperació d'un espai urbà del barri que es considera pres o privatitzat queda reflectida en accions com aquesta, però també en comentaris i opinions com la de Pierre, francès establert al barri, quan assenyala que,

"El fet que en passejar la Rambla i escoltar a la gent parlar en anglès, i estan de pas, ja que veus una ocupació de l’espai públic que no és de la gent que viu al barri, sinó que estan de pas i vénen a consumir la ciutat i el barri ... “.

Lincrement substancial del nombre d'allotjaments turístics abans ressenyat s'ha vist acompanyat, a més, d'un important increment en la privatització de l'espai urbà del barri. Els carrers i places del Poblenou s'han vist poblades, durant els últims anys, de taules i cadires de terrasses de bars i restaurants, amb especial incidència en la principal artèria del barri, la Rambla del Poblenou.

Figura 6.- $\mathrm{N}^{\circ}$ de llicències anuals, $\mathrm{n}^{\circ}$ de taules i superfície ocupada per les terrasses a la Rambla del Poblenou (2010-2018).

\section{Evolució Terrases Rambla Poblenou}

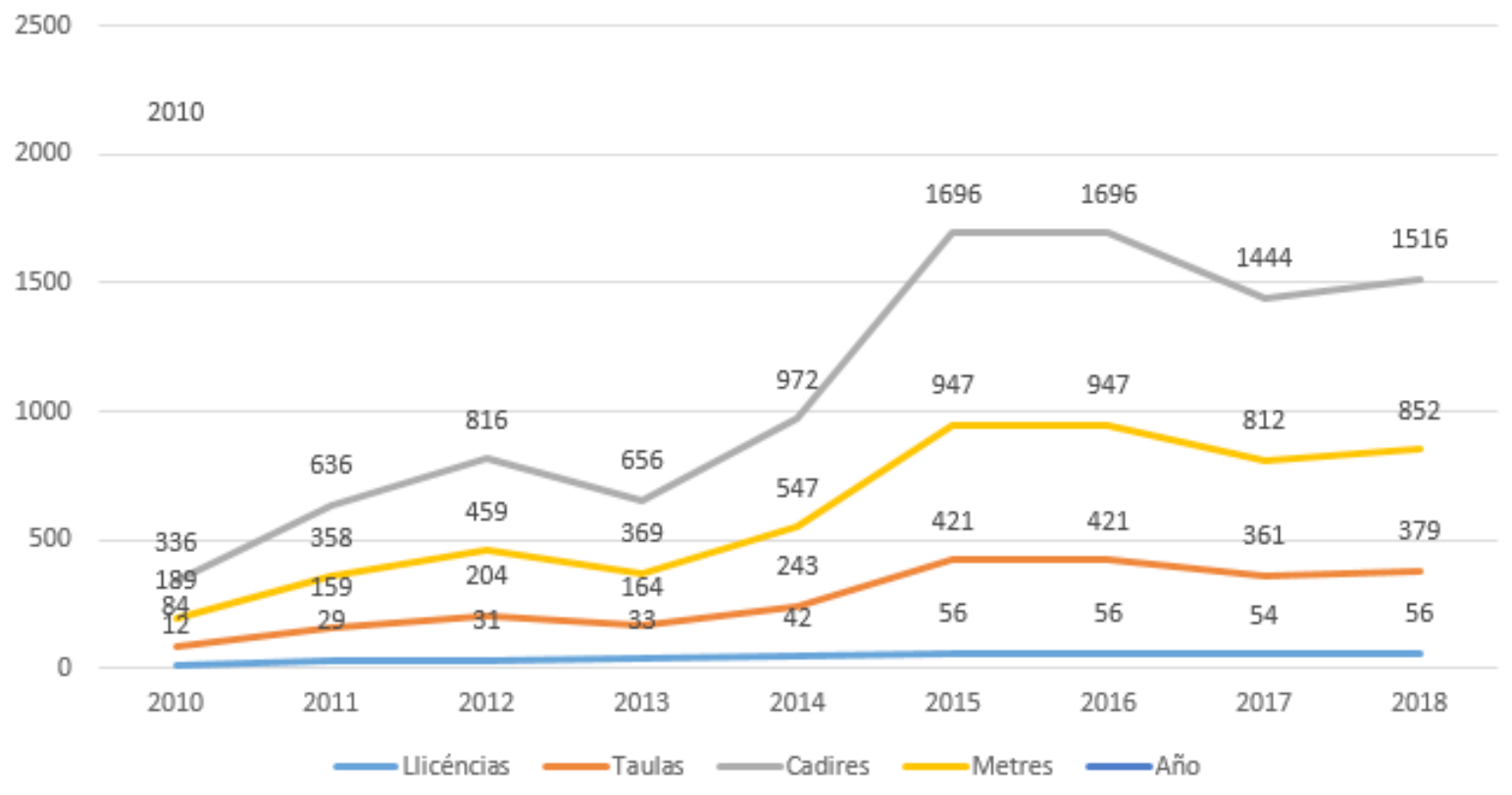

Font: Ajuntament de Barcelona, 2018 
Tal com es pot veure a la Figura 6.- entre els anys 2010 i 2018, l'espai ocupat per les terrasses es va veure multiplicat per deu, arribant als $852 \mathrm{~m}^{2}$, tot i que amb un pic de 947 $\mathrm{m}^{2}$ a 2016, mentre que les llicències van passar de 12 a 56 per al mateix període ${ }^{30}$.

\section{Figura 7.- Assemblea-sopar d’\#EnsPlantem a la Rambla (14-06-2016).}

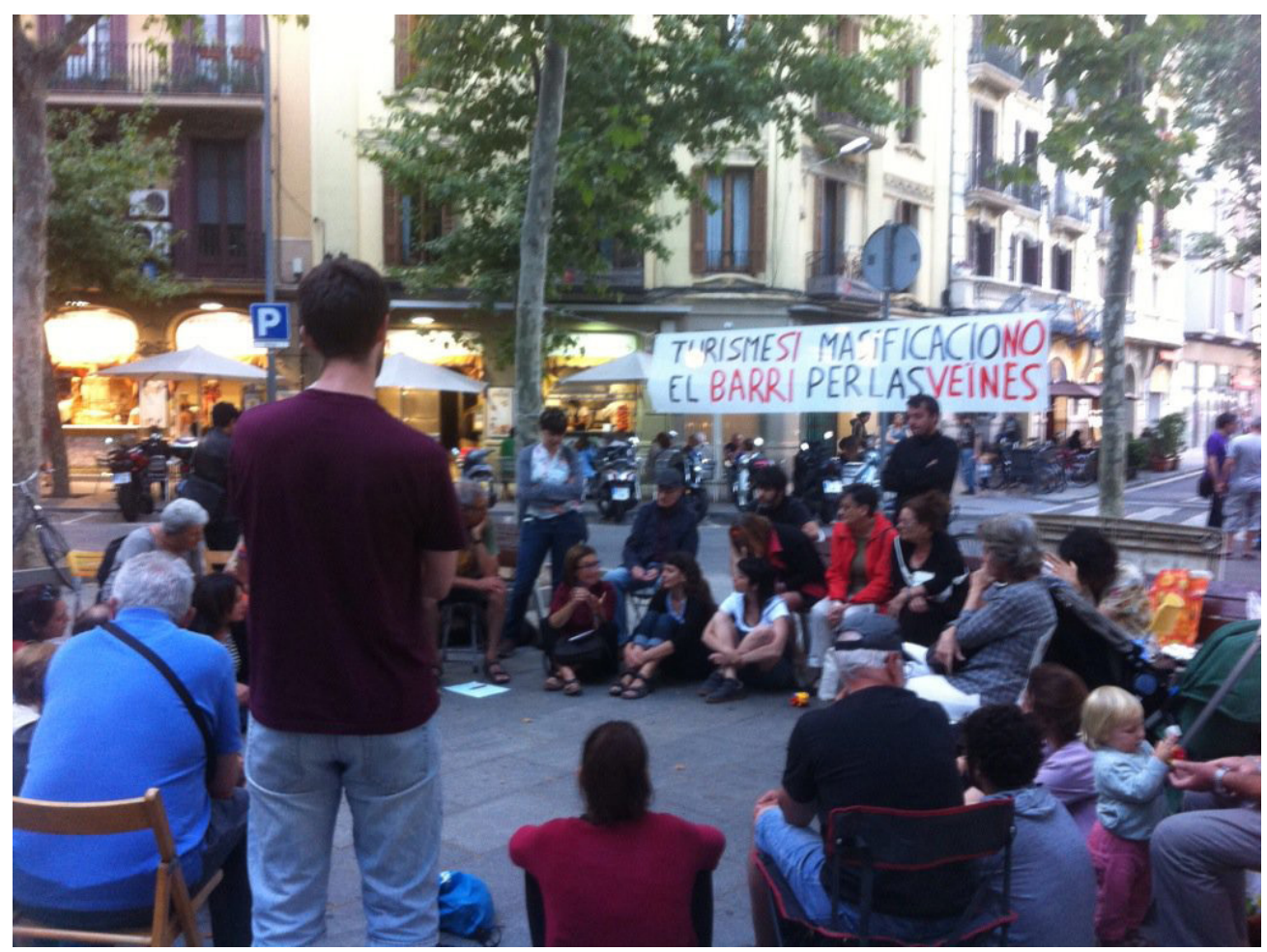

Font: @EnsPlantemP9

El novembre de 2016, l'Ajuntament va aprovar, finalment, l'ordenació singular de les terrasses de la Rambla del barri, tal com estava previst en l'Ordenança de Terrasses de l'any 2013 per a determinats emplaçaments a conseqüència "de l'estructura de l'espai o qualsevol altra circumstància peculiar" ${ }^{31}$. Aquesta ordenació preveu una ocupació màxima del $40 \%$ de l'amplària del passeig i fins a un màxim de 42 taules per cada 100 metres lineals. A més, es fixa un màxim de fins a 445 taules per a la totalitat de la Rambla. Laprovació d’aquesta ordenança en mostra una disminució temporal, passant de les 421 de l'any 2016 a les 361 de l'any següent. Així i tot, en 2018 el nombre de terrasses comença, un altre cop, la seva escalada, situant-se en les 379 . Segons un membre tècnic de Barcelona en comú del Districte Sant Martí,*

30. El període de creixement més exponencial, entre 2013 i 2015, coincideix amb els anys del Govern de Convergència i Unió ( $\mathrm{CiU}$ ) al capdavant de l'Ajuntament de Barcelona que, de fet, va aprovar una nova Ordenança de Terrasses molt més permissiva que l'anterior, impulsant enormement el nombre de llicències.

31. Butlletí Oficial de la Província de Barcelona (BOPB). Per a més informació: https://bop.diba.cat/ scripts/ftpisa.aspx?fnew?bop2013\&12\%2F022013032523.pdf\&1 
"La reducció dels dos últims anys, en aplicació de lordenació singular, és bastant bèstia (sic) en el tram central, però queda 'maquillada' per l'ampliació de llicències que ha estat possible en els trams superiors a Pere IV, és a dir, la Rambla Nova “.

Com a conseqüència de l'entrada en vigor de la nova normativa, l'espai central de la Rambla, situat entre els carrers Pere IV i Taulat, sí que ha vist disminuir la seva concentració de taules i cadires de terrasses, però això s'ha vist compensat amb un increment en la part superior, això és, entre Pere IV i Diagonal. Aquesta és la raó per la qual hi ha una aparent disminució en el nombre de taules, cadires i superfície, però un manteniment del nombre de llicències.

Aquest resultat no inesperat de la posada en marxa de l'ordenació singular ha portat els membres d'\#EnsPlantem a demanar-ne una reforma més exigent i a participar, conjuntament amb altres collectius de la ciutat, en una demanda col-lectiva per una "una política d'inspecció i sanció seriosa i rigorosa"32.

Finalment, la denúncia que \#EnsPlantem porta a terme sobre la privatització de l’espai urbà del barri sảamplia, també, a les platges properes. Un petit grup d’activistes va recórrer la Rambla del Poblenou el juliol de 2017 exigint recuperar l'espai públic de les platges, copat per "les hamaques de pagament que ocupen l'espai de la sorra" (Beteve, 2017) ${ }^{33}$.

Figura 8.- Acte de protesta a la platja de la Marbella (09-07-2017).

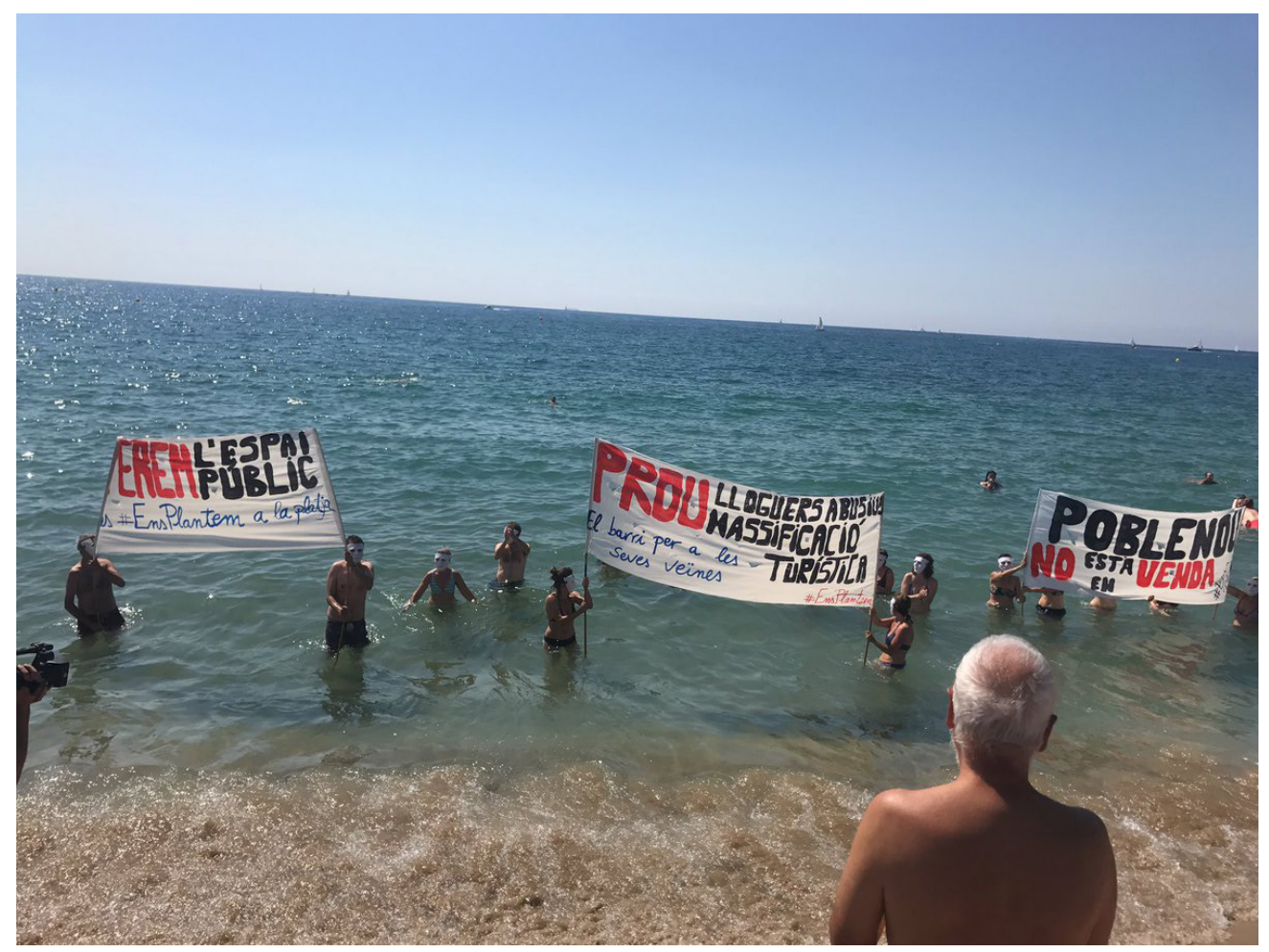

Font: @EnsPlantemP9

32. Per a més informació: https://twitter.com/AssBarrisTS/status/975275840798937089

33. Per a més informació: http://beteve.cat/nova-protesta-poblenou-contra-massificacio-turistica/ 


\section{CONCLUSIONS}

L'espai urbà de les ciutats contemporànies, com a espai social, és a dir, aquell on es projecten les estructures socials, les representacions i els mites de la societat, és també lespai on es manifesten els conflictes generats per les diferents classes socials, ètnies, sexes, etc. que la componen (Hérin, 1982). A la Barcelona contemporània, la importància que el turisme i les seves activitats ha acabat aconseguint en el sistema socioeconòmic productiu local ha dotat de característiques pròpies aquesta conflictivitat.

La posada en valor d'elements patrimonials, béns naturals i culturals, espais i entramats socials anteriorment aliens a les dinàmiques mercantils ha generat una resposta social articulada i específica -qualificada injustament com turismefòbia des de determinats mitjans- que subratlla i ataca alguns dels principals impactes que la turistificació ha fet aflorar: la pujada dels preus de l'habitatge, els canvis en l'estructura productiva local i el paisatge urbà, i la privatització de l’espai públic d’alguns dels més significatius carrers i places dels barris.

La plataforma \#EnsPlantem, Veïns en Perill d'Extinció, ha desenvolupat, des del seu naixement el maig de 2016, tot un ampli ventall de respostes a les tensions urbanes sobrevingudes. Com a moviment social ha destacat, principalment, per la varietat d'accions realitzades, les quals han anat des de locupació simbòlica i material de solars abandonats i espais públics emblemàtics del barri, passant per la mateixa incidència política davant partits i institucions, fins a arribar a lorganització de manifestacions, desfilades i assemblees obertes de denúncia i proposta d’alternatives.

La seva coordinació amb altres organitzacions, tant de barri -Comissió d'Habitatgecom a nivell de ciutat, ha quedat també palesa. La continuïtat manifesta d'\#EnsPlantem amb iniciatives anteriors del mateix Poblenou -l'Assemblea Social del Poblenou (ASP9), la Flor de Maig, etc.- exemplifica la constant efervescència que generen les polítiques neoliberals implementades a Barcelona al llarg de les darreres dècades; unes polítiques en què, com assenyala Sara Gonzalez (2005), seguint a Harvey (1985), té molta importància l'escala, ja que els processos d'acumulació del capital tenen una coherència estructural temporal, de manera que el conflicte tendeix a contenir-se i canalitzar-se en el seu salt, fent necessària l'articulació de propostes a diferents nivells territorials per fer-hi front. És precisament aquesta disputa al voltant d'allò glocal (Swyngedouw, 1997) el que ha portat a \#EnsPlantem a coordinar-se a nivell ciutat amb moviments com l'Assemblea de Barris per un Turisme Sostenible (ABTS), i aquest, al seu torn, a crear i participar darrerament a la xarxa \#SETNet (Ciutats i Regions del Sud d'Europa contra la turistificació) ${ }^{34}$.

34. Per a més informació: https://assembleabarris.wordpress.com/2018/04/26/roda-de-premsa-resentacio-de-la-xarxa-setnet-del-seu-manifest-fundacional-i-del-2n-forum-veinal-sobre-turisme-18-i-19-demaig/ 
En definitiva, l'orientació socioeconòmica decididament turística de la capital de Catalunya sembla assegurar la continuitat de la inherent conflictivitat urbana de la ciutat contemporània. Queda per dilucidar, cosa que quedaria per a posteriors investigacions, si els moviments socials sorgits en resposta a aquesta orientació han estat capaços de fer sentir la seva veu, de manera que les seves propostes hagin estat preses en consideració, i si la seva articulació amb diferents nivells territorials ha aconseguit vehicular una resposta coherent ja gran escala. 


\section{BIBLIOGRAFÍA}

Ajuntament de Barcelona (2015) El sector turístico en Barcelona. Barcelona: Ajuntament de Barcelona - Barcelona Activa.

Ajuntament de Barcelona (2016)22@Barcelona, 2000-2015. El districte de la innovació de Barcelonahttp://www.ajuntamentbarcelonapremsa.info/download/22 15 ANYS CATALA p.pdf[Consultat el 14 de mayo de 2018]

Ajuntament de Barcelona (2016b) Plan Estratégico de Turismo de Barcelona 2020. Diagnosis estratégicahttp://ajuntament.barcelona.cat/turisme/sites/default/files/ diagnosi estrategica $v 1$ esp.pdf [Consultat el 14 de mayo de 2018]

Aricó, Giuseppe, Mansilla, José Antonio i Stanchieri, Marco Luca (2016) "La salvaguarda interrumpida del poder de clase. Una visión alternativa a la 'teoría de las etapas' en el urbanismo barcelonés". In Arico, Giuseppe, Mansilla, José Antonio i Stanchieri, Marco Luca (Coords.), Barrios Corsarios. Memoria histórica, luchas urbanas y cambio social en los márgenes de la ciudad neoliberal. Barcelona: Pol-len Edicions, pp. 215-255.

Aricó, GiuseppeiFernánez, Miquel (2013) “Lluitar per la ciutat en l’era neoliberal. Envers una Antropologia del Conflicte Urbà”. Quaderns-e, núm. 18 (2), pp. 6-21.

Arroyo, Francesc (1999) "Barcelona construyó la Villa Olímpica sobre los restos de un área industrial degradada”. El País.

http://elpais.com/diario/1999/11/19/andalucia/942967331 850215.html [Consultat el 14 de mayo de 2018]

Berg, Bruce L. (2007) Qualitative research methods for the social sciences. Boston: Allyn and Bacon.

Bernard, H. Rusell (2006) Research methods in anthropology: Qualitative and quantitative approaches. Lanham: Altamira Press.

Benvenuty, L. (2017) "Los hoteles exigen a Colau que ponga fin a la turismefòbia". La Vanguardiahttp://www.lavanguardia.com/local/barcelona/20170509/422401678446/ turismefòbia-hoteleros-ayuntamiento-ada-colau-vandalismo.html[Consultat el 14 de mayo de 2018]

Bourdieu, Pierre (1997) Razones prácticas. Sobre la teoría de la acción. Barcelona: Anagrama.

Brenner, Neil, Peck, Jamiei Theodore, Nik (2015) "Urbanismo neoliberal. La ciudad y el imperio de los mercados". In Observatorio Metropolitano de Madrid (Ed.), El mercado contra la ciudad. Globalización, gentrificación y políticas urbanas. Madrid: Traficantes de Sueños, pp. 211-244. 
Caimanque, Rodrigo (2015) "Regeneración urbana y la disputa por el espacio urbano: el caso de Valparaíso, Chile”. In Aricó, Giuseppe, Mansilla, José Antonio i Stanchieri, Marco Luca (coord.) Mierda de ciudad. Una rearticulación crítica del urbanismo neoliberal desde las ciencias sociales. Barcelona: Pol-len Editorial, pp. 32-44.

Capel, Horacio (2005). El Modelo Barcelona: un examen crítico. Barcelona: Ed. El Serbal. Capel, Horacio (2016). La forma urbana en la ciudad postcapitalista. Biblio3W, Revista Bibliográfica de Geografía y Ciencias Sociales, Vol. XXI, nº1.177http://www.ub.edu/ geocrit/b3w-1177.pdf [Consultat el 14 de mayo de 2018]

Castán, Patricia (2018) "Barcelona batió sus récords de turismo de congresos en el 2017". El Periódicohttps://www.elperiodico.com/es/barcelona/20180502/barcelona-batio-susrecords-de-turismo-de-congresos-en-el-2017-6795414[Consultat el 14 de mayo de 2018].

Castells, Manuel (1976) La cuestión urbana. Madrid: Siglo XXI.

Castells, Manuel (1986) La ciudad y las masas. Sociología de los movimientos sociales urbanos.Madrid: Alianza Editorial.

Charnock, Greg, Purcell, Thomasi Ribera-Fumaz, Ramón (2014) "City of rents: The limits to the Barcelona model of urban competitiveness". International Journal of Urban and Regional Research, Vol. 38.1, 198-217.

Clarós, Salvador (2013) “El 22@ no s’acaba d'integrar al Poblenou”. La Veu del Carrer, $\mathrm{n}^{\circ} 18,9$.

Cordero, Allen (2006) Nuevos Ejes de Acumulación y Naturaleza. El caso del turismo. Buenos Aires: CLACSO.

Delgado, Manuel (2003) Elogi del vianant. Del "Model Barcelona" a la Barcelona real. Barcelona: Edicions de 1984.

Delgado, Manuel (2007) La ciudad mentirosa. Fraude y miseria del "Modelo Barcelona". Madrid: Libros de la Catarata.

Delgado, Manuel (2017) “Lo urbano más allá de la ciudad”. En Henri Lefebvre, El derecho a la ciudad. Madrid: Capitan Swing,pp., $\mathrm{xx}-\mathrm{xx}$

Della Porta, Donatella (2009) "Social movement studies and political violence". Centre for Studies in Islamism and Radicalisation.Aarhus: Aarhus University http://ps.au.dk/ fileadmin/site files/filer statskundskab/subsites/cir/pdf-filer/Forside h\%C3\%A6fte4. pdf[Consultat el 14 de mayo de 2018].

Diani, Mario (1992) "The concept of social movement". The Sociological Review, vol. 40, $\mathrm{n}^{\mathrm{a}} 1,1-25$. 
Diani, Mario (2010) "Struggling Movements in Dubious Opportunities - An Afterword to 'Surviving Neoliberalism: The Persistence of Australian Social Movements". Social Movement Studies, vol. 9, n² 2, pp. 229-233.

Diani, Mario y Della Porta, Donatella ([1999] 2006) Social movements. An introduction. Oxford: Blackwell Publishing.

Díaz Parra, Ibán (2009) Sevilla, cuestión de clase. Sevilla: Atrapasueños.

Díaz Parra, Ibán (2016) Sevilla 1929-1992. La producción de una mercancía. In Grupo de Estudios Antropológicos La Corrala (Ed.), Cartografía de la ciudad capitalista. Transformación urbana y conflicto social en el Estado español. Madrid: Traficantes de Sueños, pp. 195-118.

EFE (2017) “Turismefòbia: debate en la calle, alarma en las administraciones”. EFE.com, $\underline{\mathrm{i}}$ Florida, Richard (2009a) Las ciudades creativas. Porqué donde vives puede ser la decisión más importante de tu vida. Barcelona: Grupo Planeta.

Florida, Richard (2009b) La clase creativa: La transformación de la cultura del trabajo y el ocio en el siglo XXI.Barcelona: Grupo Planeta.

Fuller, Henning y Michel, Boris (2014) 'Stop Being a Tourist!' New Dynamics of Urban Tourism in Berlin-Kreuzberg. International Journal of Urban and Regional Research, vol. 38.4, pp. 1.304-1.318.

García Herrera, Luz Marina, Smith, Neil y Mejías, Miguel Angel (2007) "Gentrification, displacement and tourism in Santa Cruz de Tenerife". UrbanGeography, 28, 3, pp. 276298.

González, Sara (2005) "La geografía escalar del capitalismo actual”. Scripta Nova, Revista Electrónica de Geografía y Ciencias Sociales, Vol. IX, núm. 189http://www.ub.edu/geocrit/ $\underline{\mathrm{sn} / \mathrm{sn}-189 . \mathrm{htm}}$ [Consultat el 14 de mayo de 2018].

Guterman, Bruna, Sánchez, FernandaiLaiber, Paula (2015) “Río Olímpico 2016: ciudad maravillosa es la que lucha”. In Aricó, Giuseppe, Mansilla, José Antonio iStanchieri, Marco Luca (coord.) Mierda de ciudad. Una rearticulación crítica del urbanismo neoliberal desde las ciencias sociales. Barcelona: Pol-len Editorial, pp. 110-122.

Gruter, Monique (2013) "Impactos negativos del turismo". In Torres Lezama, VicenteiAraujo, Edward Pierre (comp.) Antropología del Turismo. La industria sin chimeneas. Cuzco: Tinkuy, pp. 63-70.

Harvey, David (1985) The Urbanization of Capital. Oxford: Blackwell.

Harvey, David (2001) Espacios del capital. Hacía una geografía crítica. Madrid: Akal.

Harvey, David (2007) Breve historia del neoliberalismo. Madrid: Akal. 
Harvey, David (2013) Ciudades rebeldes. Del derecho a la ciudad a la revolución Urbana. Madrid: Ed. Akal.

Herin, Robert (1982) "Herencias y perspectivas en la geografía social francesa". GeoCrítica: Cuadernos Críticos de Geografía Humana, nº41, 26-33 http://www.ub.edu/ geocrit/geo41.htm [Consultat el 14 de mayo de 2018].

Hiernaux, Daniel i González, Carmen Imelda (2014) “Turismo y gentrificación: pistas teóricas sobre una articulación".Revista de Geografía Norte Grande, n56, sept. 2014. https://scielo.conicyt.cl/scielo.php?script=sci arttext\&pid=S071834022014000200004[Consultat el 14 de mayo de 2018].

Huete, Raqueli Mantecón, Alejandro (2018) "El auge de la turismofòbia, ¿hipótesis de investigación o ruido ideológico?”. Revista PASOS, vol. 16, nº 1, pp. 9-19.

Judd, Dennis (2003) "Visitors and the spatial ecology of the city". In Hoffman, Lily M., Fainstein, Susan and Judd, Dennis R. (Eds.), Cities and Visitors. Regulating people, markets and city space. Oxford: Blackwell Publishing, pp. 23-38.

Judd, Dennisi Parkinson, Michael (Eds.) (1990) Leadership and urban generation: Cities in North America and Europe. Thousand Oaks: Sage Publications.

Kling, Joseph M. i Posner, Prudence S. (1990) "Class and community: Theories of activism in the era of urban transformation". In Kling, Joseph M. y Posner, Prudence S. (Orgs.), Dilemmas of Activism: Class, Community and the Politics of the Local Mobilization. Filadelfia: Temple UniversityPress, pp. 23-45.

La Vanguardia (2016) "Ocupación simbólica de un solar en el Poblenou contra la construcción de dos nuevos hoteles". La Vanguardia. http://www.lavanguardia.com/ local/barcelona/20160606/402320665446/ocupacion-solar-poblenou-turismo-hoteles. html[Consultat el 14 de mayo de 2018].

Lefebvre, Henri (2013) La producción del Espacio. Madrid: Capitán Swing.

Lloyd, Richard (2002) "Neo-bohemia. Art and neighborhood redevelopment in Chicago". Journal of UrbanAffairs, vol. 24, 5, pp. 517-532.

López-Vallejo, Helena (2018) “Solidaridad en el Poblenou contralos 'desahuciosinvisibles"'. El Periódico.https://www.elperiodico.com/es/barcelona/20180505/solidaridad-vecinalcontra-los-desahucios-invisibles-6801513 [Consultat el 14 de mayo de 2018].

Makhlouf, Muna (2014) “Transformaciones urbanísticas y movimientos vecinales actuales. El caso de la Barceloneta, Barcelona”. Actas delXIII Coloquio Internacional de Geocrítica, El control del espacio y los espacios de control. http://www.ub.edu/geocrit/ coloquio2014/Muna\%20Makhlouf\%20De\%20la\%20Garza.pdf [Consultat el 14 de mayo de 2018] 
Mansilla, José Antonio (2014) "La Flor de Maig somos nosotros. Geografía urbana de la memoria en el Poblenou, Barcelona”. Scripta Nova, Revista Electrónica de Geografía y Ciencias Sociales, Vol. XVII, 146 (137) http://www.ub.edu/geocrit/sn/sn-493/493-05. pdf[Consultat el 14 de mayo de 2018]

Mansilla, José Antonio (2018) "Espai, capital i cultura: el cas de la mesquita de Premià de Mar" [Reseña]. Revista Andaluza de Antropología, n¹5 (octubre 2018).

Marrero, Isaac (2003) “¿Del Manchester catalán al SoHo barcelonés? La renovación del barrio del Poblenou en Barcelona y la cuestión de la vivienda". Scripta Nova, Revista Electrónica de Geografía y Ciencias Sociales, Vol. XVIII, n493 (05). http://www.ub.edu/ geocrit/sn/sn-146(137).htm[Consultat el 14 de mayo de 2018].

Mayer, Margit (2016) "Neoliberal Urbanism and Uprising Across Europe".In Thörn, Hakand, Mayer, Margiti Thörn, Catharina (ed.), Urban Uprisings Challenging Neoliberal Urbanism in Europe. Londres: MacmillanPublishersLtd, pp. 57-92.

Medela, Juan i Salguero, Oscar (2016) “Granada(s), un tronco, muchas ramas". In Grupo de Estudios Antropológicos La Corrala (Ed.), Cartografía de la ciudad capitalista. Transformación urbana y conflicto social en el Estado español. Madrid: Traficantes de Sueños, pp. 249-274.

Milano, Claudio (2017) "Turismobofia: cuando el turismo entra en la agenda de los movimientos sociales". Marea Urbana, nº 1, pp. 5-8.

Navas Perrone, María Gabriela (2016) "La vocación utópica del urbanismo: el caso de la Vila Olímpica de Barcelona”. Actas del XIV Coloquio Internacional de Geocrítica, Las utopías y la construcción de la ciudad del futuro. http://www.ub.edu/geocrit/xiv-coloquio/ MGabrielaNavas.pdf[Consultat el 14 de mayo de 2018].

Nicholls, Walter (2008) "The urban question revisited: the importance of cities for social movements". International Journal or Urban and Regional Research, vol. 32 (4), pp. 841859.

Posthill, John (2015) "Digital ethnography: 'being there' physically, remotely, virtually and imaginatively". Johnposthill.comhttps://johnpostill.com/2015/02/25/digitalethnography-being-there-physically-remotely-virtually-and-imaginatively/ [Consultat el 14 de mayo de 2018].

Romero, Carlos (2001) "Ciudad, cultura y turismo: calidad y autenticidad". Revista PH, 36, 100-109.

Russo, Antonio Paolo i Richards, Greg (2016) "Reinventing the local tourism. Producing, consuming and negotiating place”. Bristol: Channel View Publications 
Savall, Cristina (2017) "La tensión entre vecinos y hoteles vive suprimeraaltercadoen Poblenou”.El Periódicohttps://www.elperiodico.com/es/barcelona/20170506/ una-manifestacion-contra-el-turismo-en-poblenou-termina-con-incidentes6020291[Consultat el 14 de mayo de 2018].

Slater, Tom (2011) ·Gentrification of the city". In The New Blackwell Companion to the City. Londres: Ed Blackwell Publishing Ltd, pp. 571-585.

Smith, Neil(Smith, [1996] 2012) La nuevafronteraurbana. Ciudad revanchista y gentrificación. Madrid: Traficantes de Sueños.

Swyngedouw, Erik (1997) "Neither Global nor Local. 'Glocalization' and the politics of scale". In COX, K. (ed.) Spaces of globalization. Reasserting the power of the local. New York: GuilfordPress, pp. 137-166.

Tatjer, Mercè (1973) La Barceloneta del siglo XVIII al Plan de la Ribera. Barcelona: Los Libros de la Frontera.

Tello, Rosa (1993) "Barcelona post-Olímpica: De ciudad industrial a escenario de consumo". Estudios Geográficos, Tomo LIV, 212, pp. 507-220.

Thörn, Hakand (2012) "In between social engineering and gentrification: Urban restructuring, social movements and the place politics of open space". Journal of Urban Affairs, 34 (2), pp. 153-168.

Thörn, Hakand, Mayer, Margiti Thörn, Catharina (2016) "Re-Thinking Urban Social Movements, 'Riots' and Uprisings: An Introduction”. En Thörn, Hakand, Mayer, MargitiThörn, Cathatina (ed.), Urban Uprisings Challenging Neoliberal Urbanism in Europe. Londres: Macmillan Publishers Ltd, pp. 3-56.

Tilly, Charles (1977). From mobilization to revolution. Michigan: Centre for Research on Social Organization.

Velasco, Honorioi Díaz de Rada, Ángel (1997) La lógica de la investigación etnográfica. Un modelo de trabajo para etnógrafos de escuela. Madrid: Trottam.

Zúñiga, Federico (2014) "Nuevos usos del patrimonio arqueológico de el Tajín a través de los procesos de turistificación, mercantilización y espectacularización”. In Anales de Antropología, n², vol. 48, pp. 151-182.

\section{Llistat de persones entrevistades:}

\#EnsPlantem, veïns en perill dextinció

- $\quad$ Rosa 
Ateneu la Flor de Maig/Assemblea Social del Poblenou (ASP9)

- $\quad$ Roser

- $\quad$ Pierre

Comissió d'Habitatge del Poblenou/Associació de Veïns i Veines del Poblenou (AVVP9)

- $\quad$ Robert

Ajuntament de Barcelona

- Tècnic Districte, polític Barcelona en Comú 